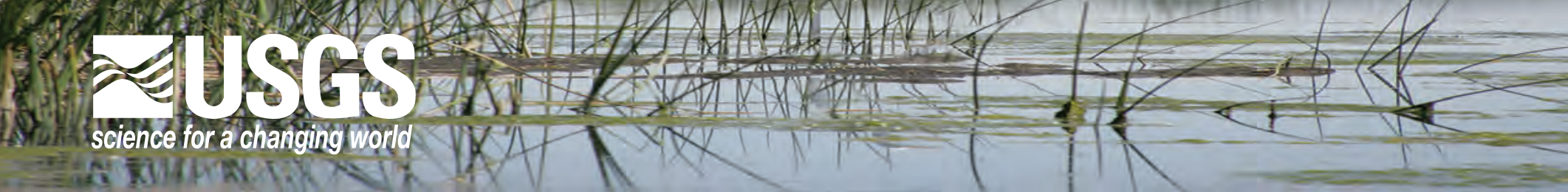

\title{
USGS Science at Work in the San Francisco Bay and Sacramento-San Joaquin Delta Estuary
}

he San Francisco Bay and Sacramento-San
Joaquin Delta form one of the largest estuaries in the United States. The "Bay-Delta" system provides water to more than 25 million California residents and vast farmlands, as well as key habjtat us, for birds, fish, and other wildlife. To help ensure the health of this crucial estuary, the U.S. Geological Survey, in close cooperation with partner agencies and organizations, is providing science essential to addressing societal issues associated with water quantity and quality, sediment transportation, environmental contamination, animal health and status, habitat restoration, hazards, ground subsidence, and climate change.

Mount Diablo during sunrise over the Sacramento-San Joaquin Delta. Inset shows a Great Egret (Ardea alba) standing in the shallows of the Delta. (U.S. Geological Survey photos by Francis Parchaso.)

Covering more than 1,600 square miles, the San Francisco Bay and Sacramento-San Joaquin Delta together form the largest estuary on the west coast of the Americas. The "Bay-Delta" is home to nearly 10 million people and is valued for its beauty, Mediterranean climate, and recreational opportunities. The estuary is also home to a diverse community of plants and animals and is the hub of California's freshwater-delivery system to move water from the north to the southern part of the State. It drains a watershed of more than 75,000 square miles that covers more than 40 percent of California. This system is a source of water for more than 25 million Californians and more than 4 million acres of farmland in the Sacramento-San Joaquin (Central) Valley.

The U.S. Geological Survey (USGS) works in close cooperation with scientists and managers from Federal, State, and local agencies; academia; and the general public to ensure that objective and credible science is available to the decision-making processes for management of the Bay-Delta. USGS research and data collection efforts in the region are funded from a wide variety of sources, and the results are used by State and Federal regulatory and management agencies, stakeholders, and the public. Currently, USGS scientists are working on more than 90 research studies in the Bay-Delta.

\section{Science Coordination}

USGS scientists provide leadership in identifying science needs and coordinating science efforts with local, State, Federal, and nongovernmental-organization scientists and agencies. The USGS provides an independent Lead Scientist and program support to the Delta Science Program (formerly CALFED Science Program). This program (http:// deltacouncil.ca.gov/science-program) was established to develop scientific information and synthesis on issues crucial to managing the Bay-Delta system. USGS also supports a Lead Scientist position for the California State Coastal Conservancy's (http://scc. ca.gov) South Bay Salt Pond Restoration Project (http://www.southbayrestoration. org). In addition, USGS provides the South Bay Salt Pond Restoration Project with the science needed for adaptive management decisions, assistance with the development of restoration targets, and measurements of project success. USGS researchers also serve as technical experts for regional scientific review panels and advisory committees. The USGS Pacific Region has formed a Bay-Delta Executive Board to coordinate and facilitate cross-project communication and planning within USGS.

\section{Water Quantity and Quality}

USGS has developed and maintains a vast network of monitoring stations in the Bay-Delta that collects real-time, round-the-clock water-quantity and waterquality data. The data, including flow direction, flow speed, salinity, and clarity, are essential to research in the Delta and are used daily by State and Federal water managers to inform their decisions. Water managers manipulate both the release of water from dams and the amount of pumping in the south Delta to balance the water needs of endangered species with the needs of California's communities and agriculture. USGS also monitors water quality in the Bay through monthly sampling trips that extend into the Delta. 


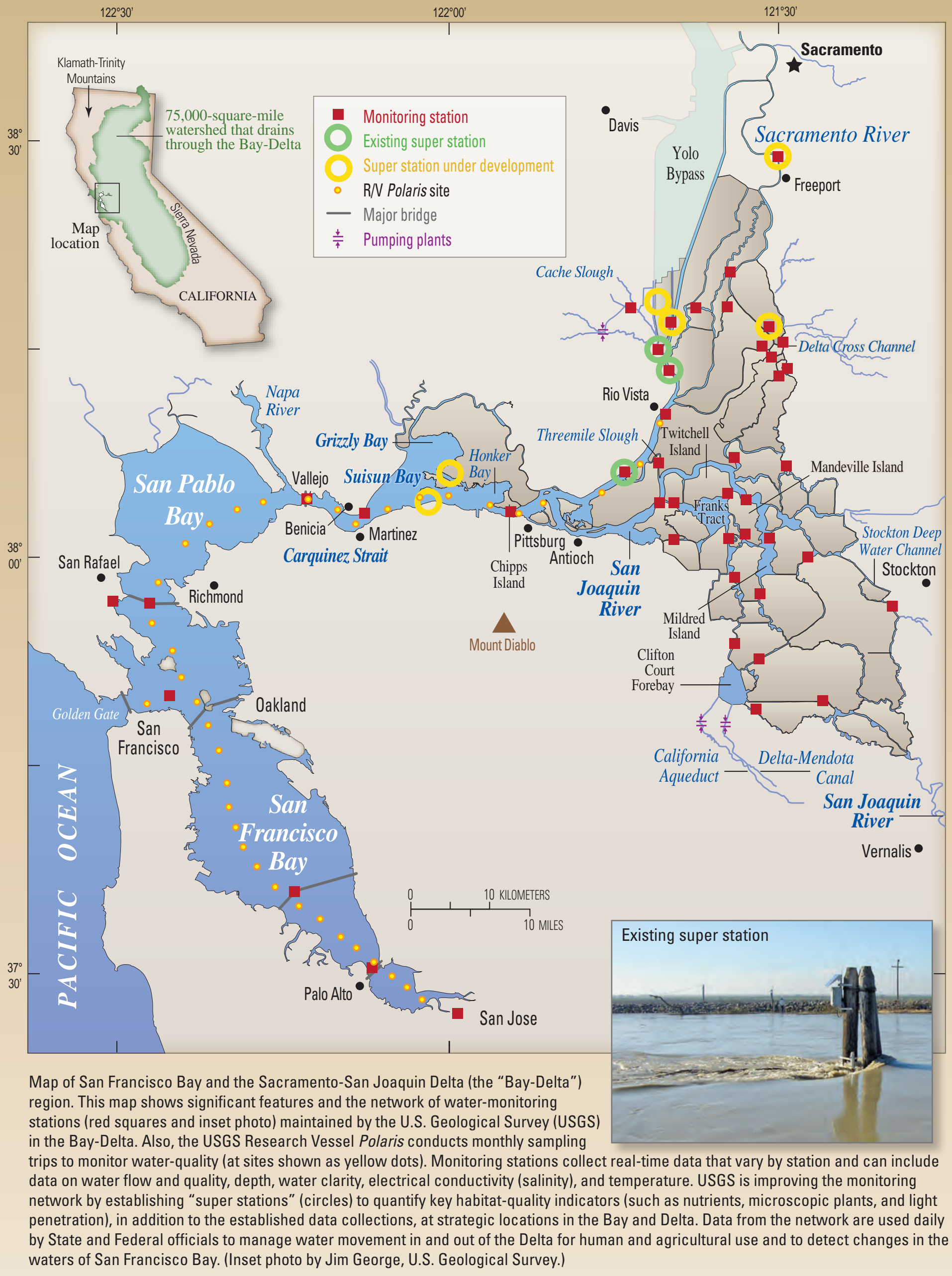


USGS scientists are also studying "stressors" to the Bay-Delta, including pesticides, trace metals, nutrients (such as nitrogen and phosphorus), and sediments in the waters of the system. USGS is currently enhancing the existing monitoring network with the establishment

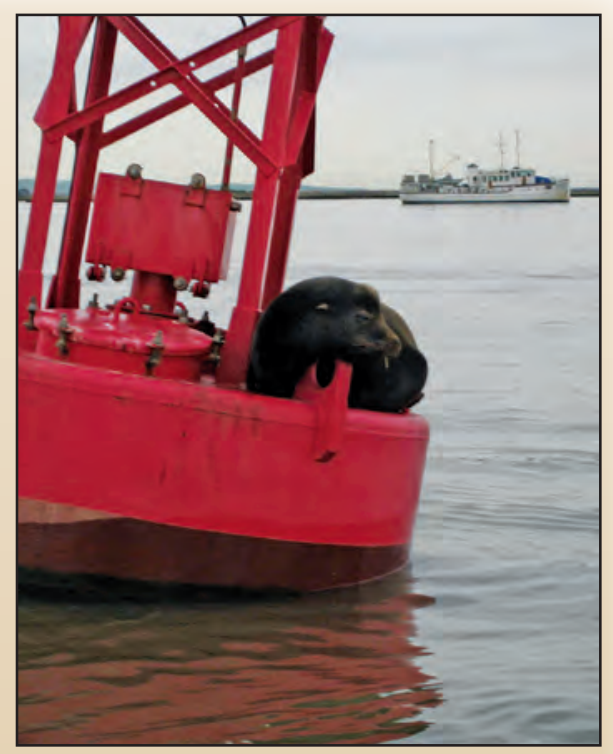

The U.S. Geological Survey's Research/ Vessel Polaris passes by a California sea lion (Zalophus californianus) resting on a buoy in Suisun Bay. The research vessel has been facilitating scientific investigations in the Bay-Delta estuary for more than 40 years. (U.S. Geological Survey photo by Francis Parchaso.)

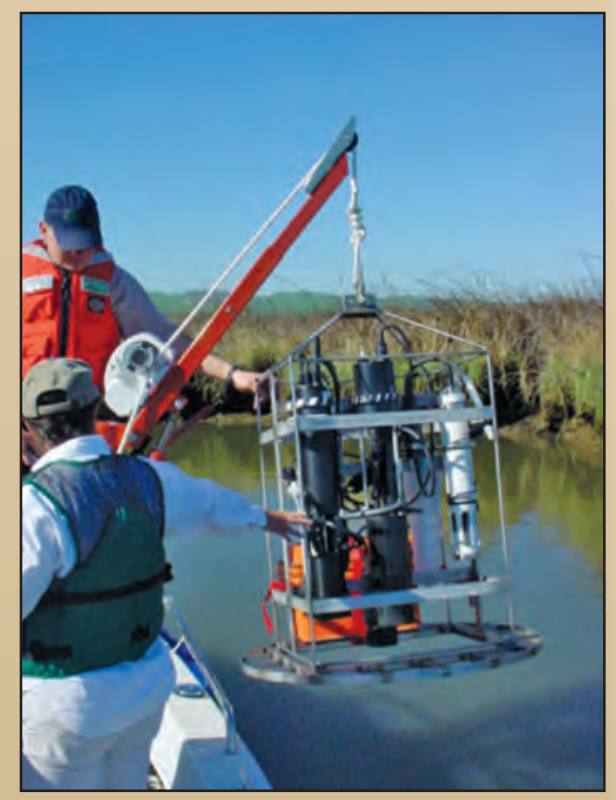

U.S. Geological Survey scientists deploying an optical instrument package at Browns Island, offshore of Pittsburg, California, to measure mercury, methylmercury, dissolved organic carbon, and nutrients in Bay-Delta waters. (U.S. Geological Survey photo by Brian Downing.) of "super stations” at strategic locations to measure habitat quality. The enhancements include adding sensors to existing stations, as well as installing several new stations, to collect data every 15 minutes on a variety of habitat characteristics. These characteristics include nutrients, phytoplankton (microscopic plants), light penetration into the water, and dissolved organic material (such as that from plant remains). These potential stressors or characteristics may have biological and ecological consequences for the food web in the Bay-Delta, which in turn may affect the health of species populations.

\section{Sediment Transport}

USGS monitors water clarity (turbidity) in the Bay-Delta using an extensive network of monitoring instruments, in cooperation with other researchers and agencies. Monitoring turbidity and calculating suspended sediment enables USGS scientists to provide crucial information for agencies and groups interested in fish conservation, specifically for the endangered Delta Smelt (Hypomesus transpacificus), as high turbidity (low clarity) may provide protection for small fish from predators.

USGS and its partners are interested in monitoring suspended sediment because it plays a role in determining the transport and fate of sediment-associated contaminants. Sediments transported by rivers into the Delta are also important to build and sustain marshes and mud flats. Recent studies have indicated that sediment loads entering the Bay-Delta have been steadily decreasing. Current USGS research is working toward understanding this decline, how much sediment input can be expected in the future, and where sediments are being trapped. With an increased understanding of sediment transport, it may also be possible to better manage the distribution of sediments for habitat restoration, shoreline erosion control and protection, dredging projects, and in turn terrestrial species preservation.

\section{Environmental Contamination}

The Bay-Delta has a long list of contaminants of concern, including naturally occurring trace metals such as mercury and selenium, as well as pesticides and nutrients. Mercury, a highly toxic heavy metal, was used extensively in hydraulic gold mining in the Sierra Nevada and the KlamathTrinity Mountains starting in the mid-1800s. Mercury-laden sediments, carried by rivers draining these mountains, are still found throughout the Bay-Delta. USGS has been studying mercury and selenium in the BayDelta to better understand and predict the impacts these contaminants may have on wildlife and human health.

Agriculture in the Bay-Delta region accounts for a large part of California's economy. This important industry currently uses a wide variety of pesticides. For more than a decade, USGS scientists have been conducting studies to determine the occurrence and long-term fate of a number of the pesticides used in the Bay-Delta

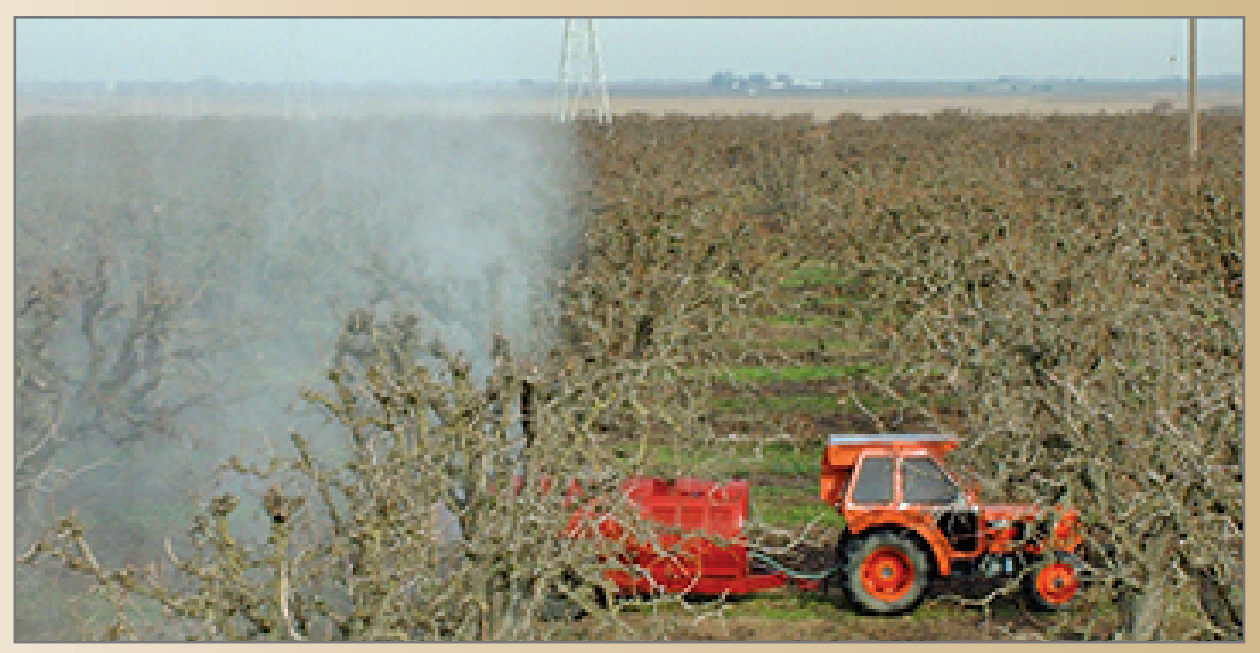

A pesticide spray is applied to a dormant pear orchard in the Sacramento-San Joaquin Delta. Agricultural and urban pesticides make their way into sediments and surface water through agricultural field and urban applications and runoff. Pesticides from such applications can also make their way into groundwater. The U.S. Geological Survey identifies and tracks pesticides in this watershed. (U.S. Geological Survey photo by Ed Moon.) 
An endangered California Clapper Rail (Rallus longirostris obsoletus) and its chick feeding at low tide in Arrowhead Marsh in Oakland, California. Studies by the U.S. Geological Survey indicate that threats to Clapper Rails include, but are not limited to, loss of habitat due to urban pressures and sea-level rise, predation, and the effects of contaminants on reproductive success. (Photo by Wendy Naruo.)

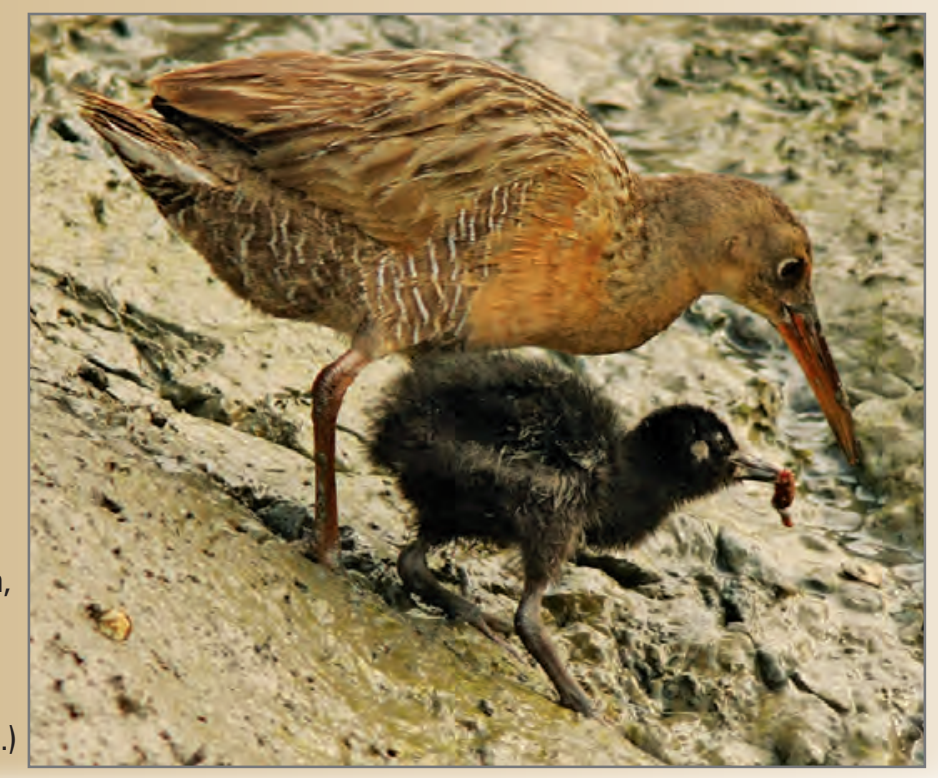

and throughout the State. USGS studies have detected an increase of pyrethroid insecticides (similar to insecticides naturally produced by chrysanthemums), which are highly toxic to aquatic invertebrates (such as insects, crabs, worms, and clams) and fish, especially cold-water fish such as salmon.

\section{Animal Health and Status}

USGS conducts a variety of studies on aquatic and terrestrial wildlife in the Bay-Delta. These range from studies on migratory birds and fish to invasive and endangered species. The Bay-Delta is a key wintering destination for migratory birds and serves as a crucial stopover on the Pacific Flyway (a major north-south route for these birds, extending from Alaska to the tip of South America). It provides essential habitat for millions of shorebirds and waterfowl. These birds face a variety of threats in the Bay-Delta, including habitat loss, loss of preferred prey due to the invasion of non-native prey species, disturbance, industrial and agricultural contamination, and climate-change-induced sea-level rise and salinity change.

USGS researchers are working to develop a scientific basis for assessing, monitoring, and restoring the health and habitat of birds such as the Surf Scoter (M elanitta perspicillata), whose populations have declined 50 to 60 percent in the past 50 years; the endangered California Clapper Rail (Rallus Iongirostris obsoletus), considered an indicator species for the health of tidal wetlands; and birds nesting on Alcatraz Island in San Francisco Bay such as Black-crowned Night-Heron (Nycticorax nycticorax) and Snowy Egret (E gretta thula). In Suisun Marsh and the
Central Valley of California, scientists are studying ducks such as Mallard (Anas platyrhynchos), Gadwall (Anas strepera), Cinnamon Teal (Anas cyanoptera), and Northern Pintail (Anas acuta).

USGS actively participates in fish research in the Delta. For example, USGS scientists are using a network of acoustic equipment to track in- and out-migrating Steelhead Trout (Oncorhynchus mykiss) and Chinook Salmon (O ncorhynchus tshawytscha) that have been fitted with sound transmitters. Data from the network are being used to model the movements and behaviors of these fish, and when combined with USGS water-flow data, aid in the understanding of how flow conditions, water channel geometry, and turbidity are affecting salmon survival in the Bay-Delta. USGS is also studying factors that define the preferred habitats and migration of the Delta Smelt, which spends its entire lifespan in the estuary.

In addition to studying birds and fish, the USGS monitors benthic (bottom

\section{A Giant Garter Snake}

(Thamnophis gigas) coiled in a wetland in the Sacramento Valley. Giant Garter Snakes are only found in aquatic habitats of California's Central Valley and wetlands in the Bay-Delta and are threatened primarily by loss and degradation of wetland habitats. U.S. Geological Survey scientists study the snake's regional populations and habitat to inform the conservation of the species. (U.S. Geological Survey photo by Matt Meshriy.) dwelling) invertebrate communities (including invasive clams) in the Bay-Delta to better understand how these species are affected by environmental changes and how their behaviors affect water quality. USGS also tags and tracks the threatened Giant Garter Snake (Thamnophis gigas), endemic to wetlands of the Central Valley and the Bay-Delta.

\section{Habitat Restoration}

Much USGS research in the BayDelta assesses or informs restoration activities and contributes to comprehensive ecosystem planning documents for the Bay-Delta, such as the Delta Plan (http:// deltacouncil.ca.gov/). More than 90 percent of tidal wetlands in the Bay-Delta have been either diked or filled. USGS studies related to the restoration of more than 15,000 acres of diked salt ponds in San Francisco Bay are providing information essential to these efforts.

The USGS has multiple interconnected projects associated with the South Bay Salt Pond Restoration Project examining and predicting (1) contaminants associated with restoration management actions and their potential for impacts on aquatic species, birds, and mammals; (2) ground subsidence (sinking of the land surface), as this may affect efforts to rebuild tidal marshes; and (3) the impacts associated with breaching of levees to restore natural tidal flows.

\section{Hazards}

USGS science helps to understand and quantify the risks natural hazards pose to Bay-Delta habitats, communities, and infrastructure. Property in the Bay-Delta is often protected behind levees. Because of severe subsidence in parts of the Delta and the threat of sea-level rise from

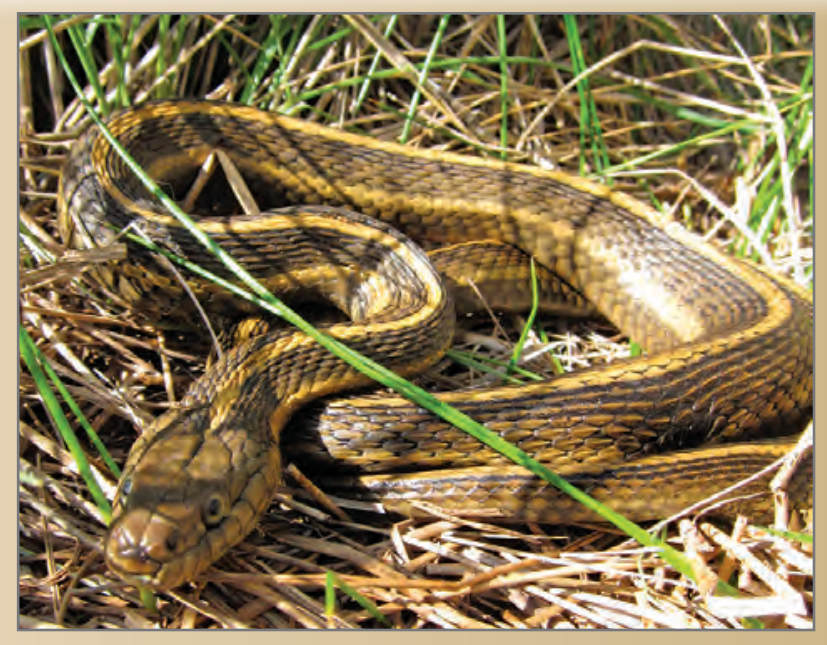




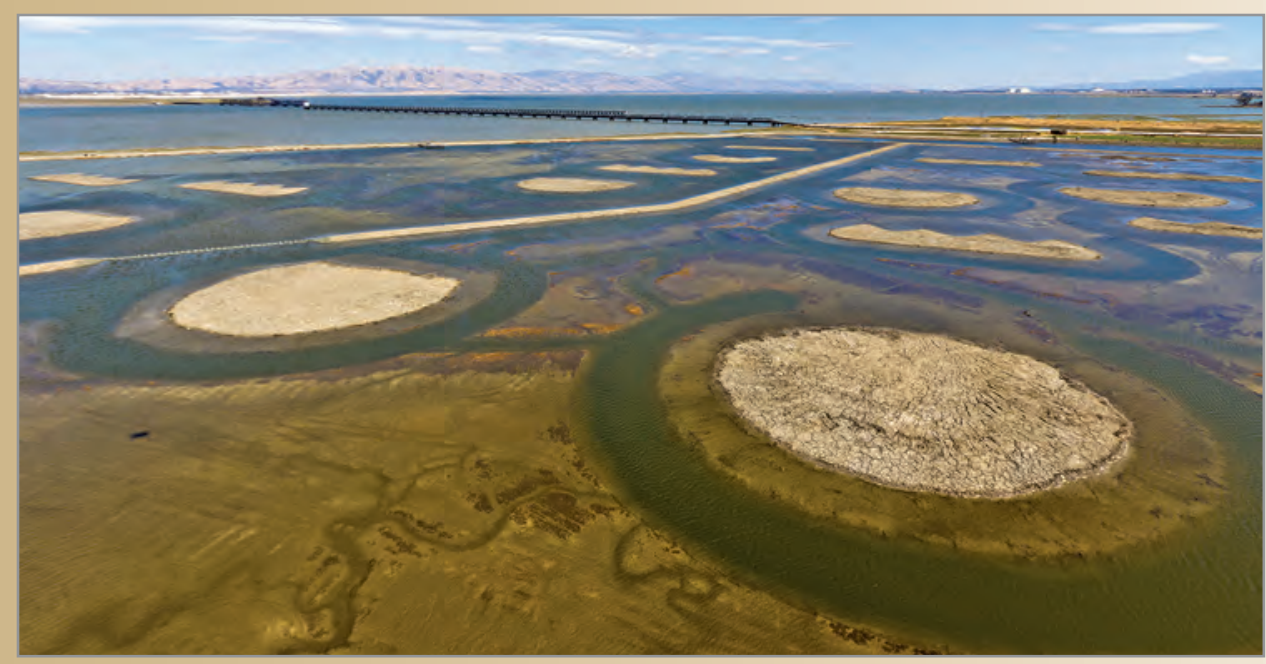

The U.S. Geological Survey guides restoration efforts in the South Bay Salt Pond Restoration Project. Engineered islands in a restored pond near Palo Alto, California, are used in an experiment to evaluate how the size and shape of an island affect waterbird nesting, resting, and feeding. Results will be used in future pond design to enhance opportunities for waterbird use and breeding success. (Photo by Charles Benton, Pelican Media Archive.)

climate change, levee stability is a primary concern in the region. USGS scientists are characterizing the subsurface geology to increase understanding of the earthquake faults that could affect the Bay-Delta and its levees. They are also developing three-dimensional (3-D) maps to determine fault locations, maximum possible quake magnitudes and fault slip rates, and how seismic waves would behave in the sandy and peaty soils of the Bay-Delta. USGS is using innovative technologies, such as lidar (light detection and ranging; a "remote-sensing" technique), to better understand (1) how subsidence and other ground movements affect levees and (2) the effects of tree roots and rodent burrows on levee stability.

Massive floods could overwhelm levees and flood adjacent communities in the Bay-Delta. To help improve flood preparedness in California, the USGS and its partners created "ARkStorm," a statewide storm disaster scenario (see http://pubs.usgs. gov/of/2010/1312/). The scenario details the potential physical, social, and economic impacts from modern-day "megastorms," similar to those in California's past, and is serving as the basis for Northern California's Catastrophic Flood Plan. ARkStorm was based on atmospheric river (AR) storms, a meteorological phenomenon. These storms are generally long and narrow, carry tremendous amounts of water vapor, and strike the west coasts of most continents and landmasses.

The extreme precipitation that they can bring could be dangerous for low-lying areas of the Bay-Delta, causing flooding, stress on levee systems, levee overtopping, and landslides. USGS is studying the impacts of previous AR storms and uses this information to inform flood-management development for the future. These analyses are also aiding in the development of a landslide vulnerability system to identify the potential for onset of landsliding that could threaten San Francisco Bay region communities.

\section{Ground Subsidence}

Beginning in the late 1800s, the nutrientrich peat soils of more than 60 islands in the Delta were cleared of vegetation and dewatered to make way for agriculture. Drainage, wind, and agricultural practices cause degradation of the peat soils releasing carbon dioxide $\left(\mathrm{CO}_{2}\right)$ into the atmosphere. Soil degradation has in turn caused the islands to subside below sea level by 9 to 26 feet or more.

USGS scientists have been studying subsidence in California for more than 60 years. Recent research has focused on how the peat soils were created and ways to mitigate or reverse soil degradation through engineering. For example, on deeply subsided Twitchell Island in the Delta, USGS spearheaded the creation of an experimental wetland that, through the growth of marsh plants, "sequestered" or stored carbon, accumulated peat sediments, and reversed subsidence.

USGS is also studying subsidence in relation to water-project canals in the Central Valley. This subsidence has occurred as a result of the extraction of groundwater for agricultural and municipal use. The USGS studies are helping to inform water-project maintenance activities and preserve the integrity of waterconveyance systems in California.

\section{Climate Change}

Projected sea-level rise and reduced winter snowpack resulting from climate change threaten future water quality and availability in the Delta, as well as the operations of State and Federal water projects. USGS is studying how climate

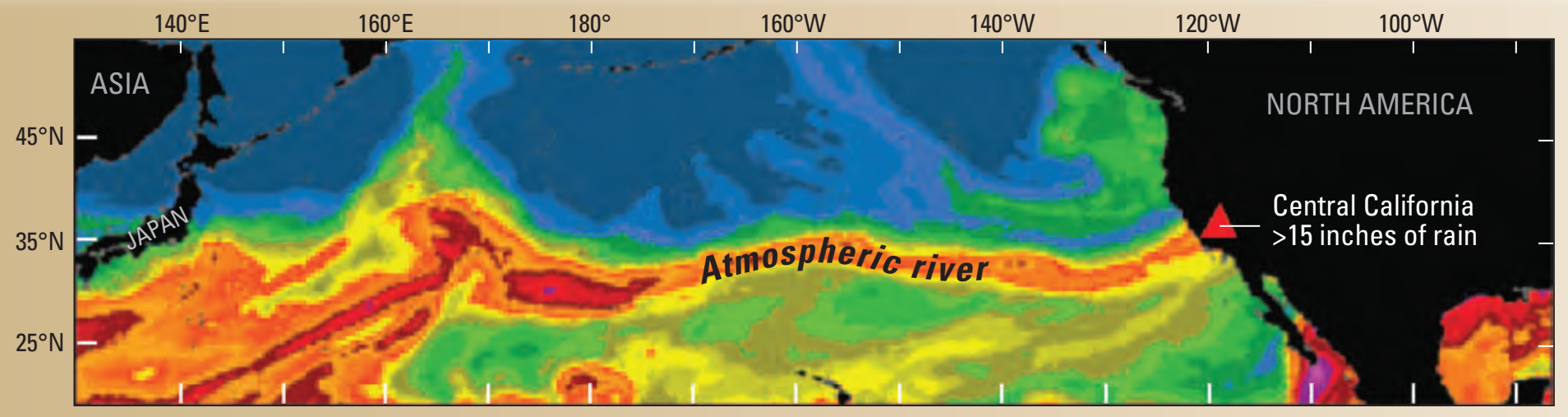

Atmospheric rivers (ARs) are a large threat to the Bay-Delta region. This image from the Special Sensor Microwave Imager satellite shows an AR that hit the California coast during 0 ctober 2009, bringing more than 15 inches of rain to central California. The colors represent water vapor in the atmosphere; warmer colors show greatest concentrations, with dark purple being the most concentrated. (Satellite image from National Oceanic and Atmospheric Administration.) 


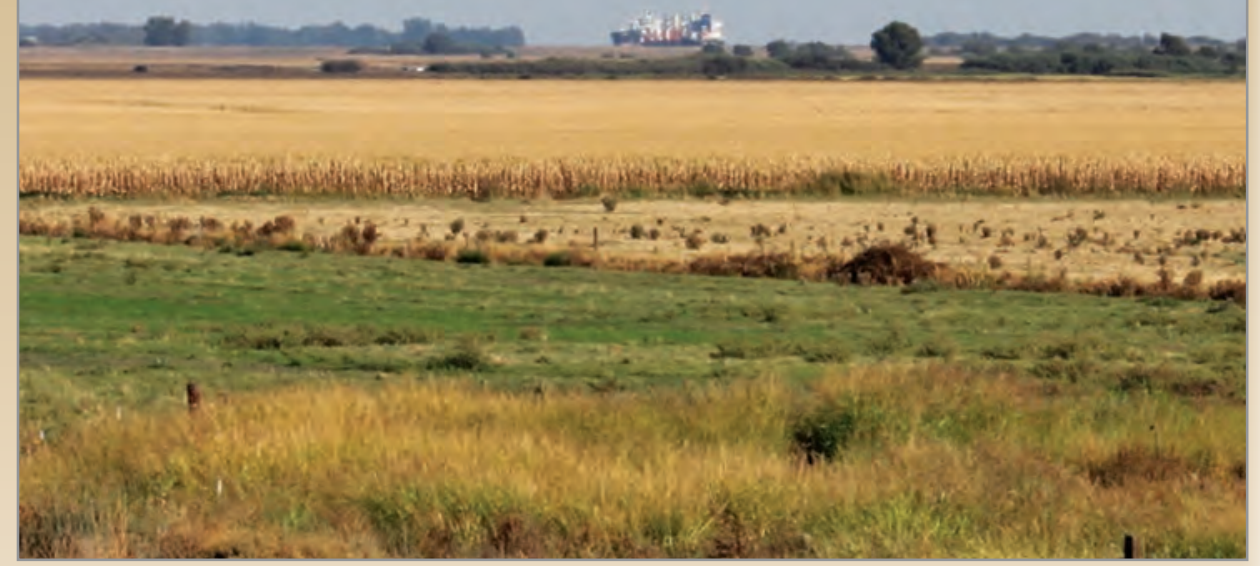

A cargo ship, heading for the Port of Stockton by way of the San Joaquin River, passes by subsided Twitchell Island. The island is surrounded by a reinforced levee that keeps surrounding waters, much higher than the island's surface, out. This is typical for an island in the central Delta. (U.S. Geological Survey photo by Michelle Shouse.)

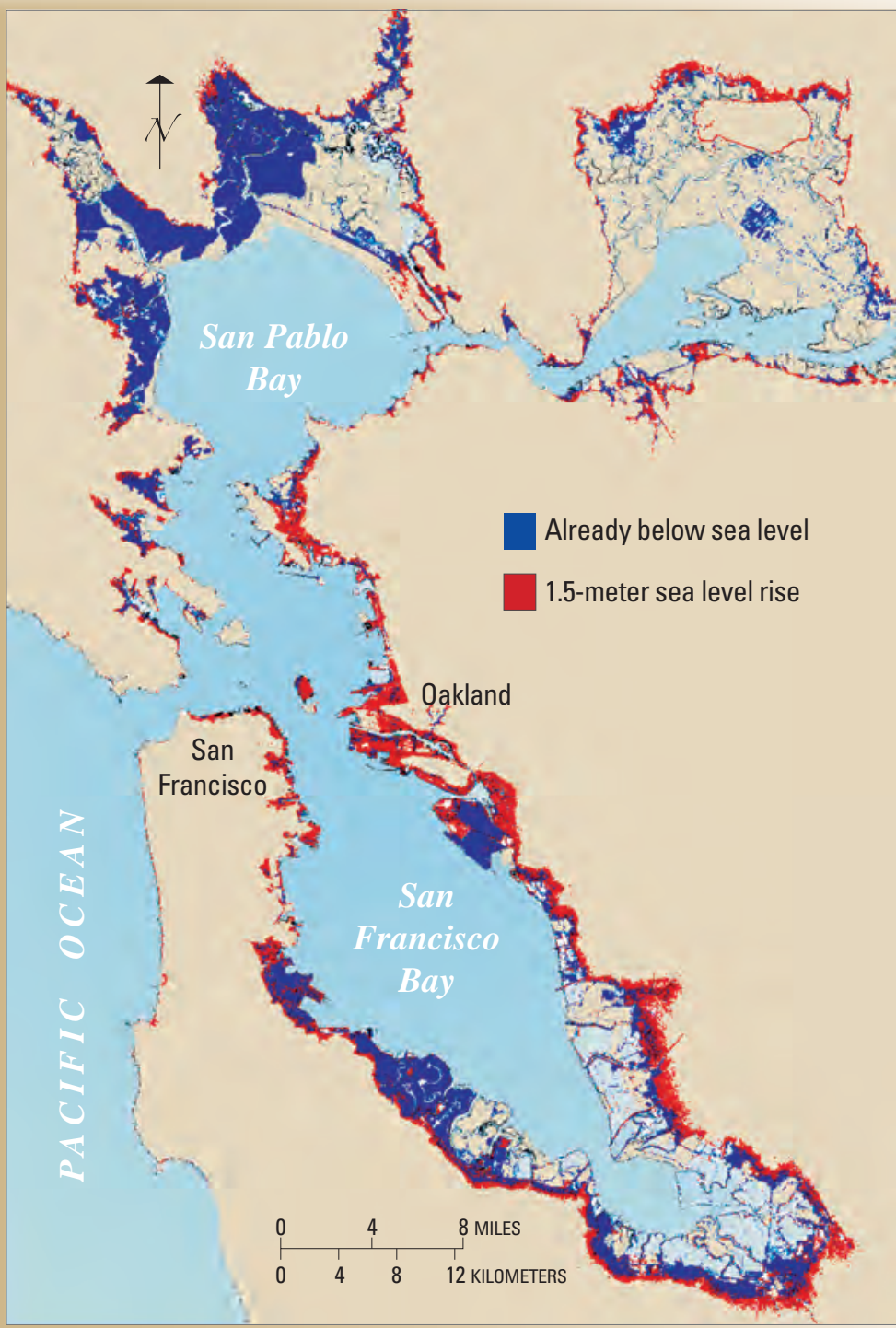

Sea-level rise due to climate change is a serious threat to waterfronts in the Bay-Delta. Many shoreline areas in the region already are below sea level (shown in blue) and are protected by levees. These areas currently are susceptible to flooding due to potential levee failure and (or) overtopping during storms. The red regions represent areas that will be inundated under a possible sea-level rise scenario of 1.5 meters ( 4.9 feet) by the year 2200 . These areas are mostly developed areas that are unprotected by levees. (U.S. Geological Survey image by Noah Knowles.) change, together with planned waterconveyance structures, may affect fish and wildlife habitat, water flow, drinkingwater quantity and quality, and agriculture. Sea-level rise will encroach on tidal marsh habitats, potentially displacing several endangered or threatened species native to tidal marshes such as the Salt Marsh Harvest Mouse (Reithrodontomys raviventris), California Clapper Rail, and California Black Rail (Laterallus jamaicensis coturniculus).

Climate induced precipitation changes that result in reduced snowpack in the Sierra Nevada and the Klamath-Trinity Mountains will affect the amount, seasonal availability, and temperature of California's freshwater resources, as well as the BayDelta. USGS science on these issues is informing decisions being made now to preserve species and resources threatened by a changing climate.

USGS scientists, working with a wide variety of partners, continue their ongoing efforts to provide the essential, objective science needed to address current and future issues in the Bay-Delta. These efforts are examples of how the USGS is fulfilling its mission to provide reliable scientific information to describe and understand the Earth; minimize loss of life and property from natural disasters; manage water, biological, energy, and mineral resources; and enhance and protect our Nation's quality of life.

Michelle K. Shouse and Dale A. Cox

Edited by J ames W. Hendley II Graphic design by Vivian T. Nguyen and J eanne S. DiLeo

For more information contact:

Michelle Shouse

U.S. Geological Survey

Office of the Pacific Regional Director

CSUS-Placer Hall, Suite 5000 $6000 \mathrm{~J}$ Street

Sacramento, CA 95819-6129

mkshouse@usgs.gov

Tel. (916) 278-9560

Or visit http://sfbay.wr.usgs.gov/

This Fact Sheet and any updates to it are available online at http://pubs.usgs.gov/fs/2013/3037/ 